\title{
Pulmonary function tests in petrol pump workers exposed for three years to petrol/diesel fumes in Mathura District Uttar Pradesh
}

\author{
Satyanath Reddy Kodidala
}

\author{
Assistant Professor, Department of Physiology, K.D Medical College, Mathura, U.P, India..
}

\begin{abstract}
Background: Occupational and environmental exposure to petroleum refinery products poses a significant threat to human health and petrol pump workers under their occupation are continuously exposed to petroleum gases and petroleum products. This community is generally neglected regarding their health. Aims and objectives: This study aimed to assess and compare the Pulmonary functions of petrol pump workers with age-sex matched normal healthy individuals by using computerized Spirometry. Methods: This is a cross-sectional study design in which 100 participants out of 50 petrol pump workers and 50 control group. Age, weight, height, ethnicity and socioeconomically matched subjects with minimum exposure of 3 years from different areas of Mathura district were recruited. Respiratory health of participants is ruled out by exclusion criteria. The Parameters TV, FVC (L), FEV1, FEV1/FVC, MVV, and PEFR are measured by computerized spirometry (Helios). Results: The Spirometry values were significantly reduced in participants working in the petrol pumps as compared to the controls. A significant decline in lung function parameters TV, FVC (L), FEV1, MVV, and PEFR was observed and no significance found in FEV1 /FVC among Petrol Pump workers when compared to controls. Conclusion: Subjects working in Petrol Pumps have significantly impaired lung functions. The lung function impairment pattern provides evidence in the favour of obstructive and restrictive lung disease and suggests improving control measures in petrol pumps .
\end{abstract}

Keywords: PFT; TV; FVC(L); FEV1; FEV1/FVC; MVV and PEFR.

\section{Introduction}

Many groups in the society are at higher risk of developing adverse consequences owing to their working environment; one such group is the petrol pump workers who under their occupation are continuously exposed to the noxious chemical compounds present in gasoline. Petrol pump workers are exposed to the petrol fumes exhibit several effects on the respiratory functions. Petrol (gasoline) is a complex combination of hydrocarbons. About $95 \%$ of the components in petrol vapour are aliphatic and alicyclic compounds and less than $2 \%$ aromatics. [1] Diesel exhaust fumes are a complex mixture of particulate and gas-phase pollutants. The highly respirable particles consist mainly of a carbonaceous core and adsorbed organic compounds. Gas -phase components, particularly SO2, may subsequently undergo gas to particle reactions and form secondary particulate. The carbon core is defined as elemental carbon (EC) and adsorbed organics as organic carbon (OC) $[2,3]$.

In Mathura District petrol pumps, there is no provision of self-service, and the fuel filling attendants are employed for the fueling of vehicles. These fuel dispensers work continuously for 8-12 hours a day without using any protective devices likely to be exposed to petrol vapours and by not maintaining personal hygiene even like consuming food without washing hands which is another

eISSN: 2523-6709

pISSN: 2523-6695

DOI: $10.31878 /$ ijcrpp.2020.41.03 method for exposure. [4] Typically, 8 hours benzene exposure concentrations in distribution and retail operations average less than $1 \mathrm{ppm}$, although exposures can reach 2-3 ppm for shorter periods (say: $30 \mathrm{~min}-120$ min) [5]. India does not have an air quality standard for benzene unlike in the UK; the permissible annual average limit is $16.5 \mathrm{mg} / \mathrm{cum}$. Apart from refueling vehicles, these workers also do all sorts of works like unloading of fuel and daily checking of fuel levels in the storage tanks, checking the pressure in vehicle tires. [6] There are many studies done in other parts of India, but no investigation was conducted in Mathura region. So, it was necessary to carry out detail study on the lung function abnormalities among petrol pump workers as such a study which is lacking in this geographical region

\section{Materials and methods}

Study design: This is a cross-sectional analytical casecontrol

Ethics approval: Ethical clearance was taken from the Institutional Ethical Committee, and each subject gave the consent, those not willing to give consent are excluded from the study.

Sampling technique: Convenient sampling method was used.

Study location: The study conducted on various petrol pump workers of the Mathura city. The examination was done in the Physiology department of KD Medical College, Uttar Pradesh.

Correspondence: Dr. K Satyanath Reddy, Assistant Professor, Department of Physiology, K.D. Medical College Hospital and Research Centre, Akbarpur, Tehsil Chhata, Mathura, U.P, India . E-Mail: ksatyanath1989@gmail.com 
Table 1: Anthropometric and Pulmonary functions of Petrol pump workers with Normal individuals

\begin{tabular}{llll}
\hline Characteristics & Controls & Exposed group & P-Value \\
\hline Age (years) & $30.40 \pm 6.75$ & $28.20 \pm 3.80$ & 0.0474 \\
Height $(\mathrm{Cms})$ & $153.26 \pm 5.72$ & $152.77 \pm 6.22$ & 0.0527 \\
Weight $(\mathrm{Kgs})$ & $65.27 \pm 8.74$ & $66.56 \pm 5.62$ & 0.3822 \\
Duration of exposure & - & $>3$ years & - \\
FVC (lts) & $3.07 \pm 0.49$ & $2.80 \pm 0.74$ & 0.034 \\
TV & $0.48 \pm 0.12$ & $0.28 \pm 0.11$ & 0.001 \\
FEV & $2.92 \pm 0.70$ & $2.12 \pm 0.48$ & 0.001 \\
MVV (ltr/min) & $81.92 \pm 5.65$ & $84.16 \pm 3.00$ & 0.015 \\
PEFR (ltr/sec) & $6.54 \pm 0.99$ & $5.12 \pm 1.48$ & 0.001 \\
FEV $/$ FVC & $3.75 \pm 0.76$ & $3.42 \pm 1.02$ & 0.069 \\
\hline
\end{tabular}

(Data was presented as Mean $\pm \mathrm{SD}$ )

$P$ value $<0.05$ is statistically significant, $P$ value $>0.05$ is considered to be statistically not significant

Study period: February 2017 to November 2017.

Participant recruitment procedure: Every consecutive individual working at petrol pump with minimum exposure of 3 years not $<8$ hours/day in different areas of Mathura city was recruited as an exposed group, whereas in the control group, the normal healthy individuals were recruited who were not regularly exposed to petrol fumes.

Inclusion criteria: The minimum working period in the industry for 3 years, age group between 20-35 years and Males were included in this study

Exclusion criteria: The participants who are having the following disease/condition were excluded

Gross anaemia, Hypertensive, Asthmatics, Diabetes mellitus, Smokers, Patient with coronary artery disease, Patients for allergic bronchitis, who had undergone abdominal or chest surgery, Neuro-muscular disease

Sample size: 385 .

The sample size (n) is calculated according to the formula: $\mathrm{n}=\mathrm{z} 2 * \mathrm{p} *(1-\mathrm{p}) / \mathrm{e} 2$

\section{Methodology:}

Tests were carried out during the morning hours between 9 AM to 11:00 AM to avoid possible diurnal variations. Subjects were briefed and familiarized and were instructed to avoid beverages and exercise one hour before reporting. The pulmonary function tests were carried out using a computerized spirometer using the standard laboratory methods. The spirometer was calibrated regularly, and a brief physical and general examination was carried out, and the anthropometric parameters (name, age, sex, height, weight, occupation, and smoker /nonsmoker) were recorded. All the pulmonary function tests were done on the subjects comfortably in an upright position and adequately encouraged to perform their optimum level, and a nose clip was applied during the entire maneuver. Tests were repeated three times, and the best matching results were considered for analysis with graphic curves was obtained.
The various Pulmonary function tests recorded were:-

- Forced vital capacity (FVC).

- Tidal volume (TV)

- Forced expiratory volume in 1st second (FEV1).

- Maximum voluntary ventilation (MVV).

- Peak expiratory flow rate (PEFR).

- FEV1/FVC

Statistical analysis: Statistical analysis was done by using SPSS software by student -t-test is used to compare mean between two variables. The significance level was $5 \%(\mathrm{P}<0.05)$, for each group.

\section{Results}

In the present study a total of hundred participants were recruited out of fifty people were working in petrol pumps, and the other fifty were normal healthy individuals who are not exposed to petrol fumes.

Table 1: Shows the anthropometric parameters exposed group (Petrol pump workers $n=50$ ) were in the age group of $28.20 \pm 3.80$ years, while the non exposed group ( $n=$ $50)$ were in the age group of $30.40 \pm 6.75$ years. The anthropometric parameters of the subjects were measured in both groups (Exposed group: Weight $=66.56 \pm 5.62 \mathrm{kgs}$, Height $=152.77 \pm 6.22 \mathrm{Cms}$, and Unexposed group: Weight $=65.27 \pm 8.74 \mathrm{kgs}$, Height $153.26 \pm 5.72 \mathrm{Cms}$ ).

Pulmonary functions were found significantly decreased in petrol pump workers. FVC of the exposed group is $3.07 \pm 0.49$ liters, and the non-exposed group is $2.80 \pm$ 0.74 liters with significance P-value 0.03 . TV of exposed group is $0.48 \pm 0.12$ liters and non-exposed group is 0.28 \pm 0.11 liters with significance P-value 0.001. FEV1 of exposed group is $2.92 \pm 0.70$ liters and non-exposed group is $2.12 \pm 0.48$ liters with significance P-value 0.001 . MVV (liters $/ \mathrm{min}$ ) of exposed group is $81.92 \pm$ 5.651 liters, and non-exposed group is $84.16 \pm 3.00$ with significance P-value 0.015. PEFR (liters $/ \mathrm{sec}$ ) of exposed group is $6.54 \pm 0.99$ liters and non-exposed group is 5.12 \pm 1.48 with significance P-value 0.001 . FEV1/FVC of 


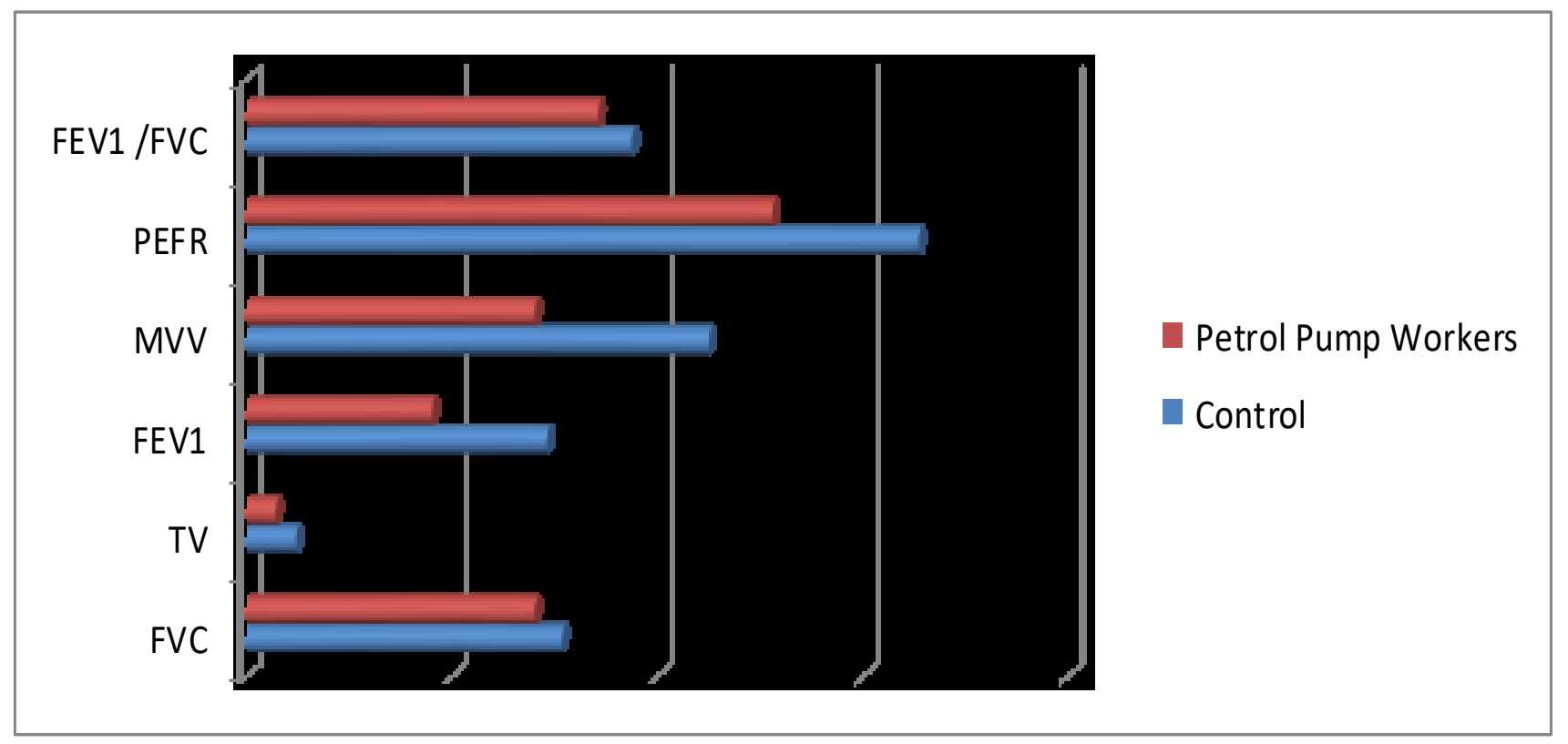

Fig 1: Comparison of pulmonary function parameters between petrol pump workers and control group.

exposed group is $3.75 \pm 0.76$, and nonexposed group is $3.42 \pm 1.02$ with significance P-value 0.069 .

\section{Discussion}

Rapidly multiplying the number of automobiles vehicles will push petrol pumps in high numbers have increased air pollution. Petrol pump workers under their occupation are continuously exposed to hazardous gaseous fumes. In the present study we have tried to asses PFT in petrol pump workers and found decline in all lung functions of their continuous exposure.

However, a statistically significant decline was noted only in FVC, FEV1, MVV, TV, FEV1\% and PEFR, among the petrol pump workers as compared to controls. Our results are similar to studies done by Nazia Uzma et al. [7]. Singhal et al. found statistically significant decrease in FVC, FEV1, and PEFR in petrol pump workers who were exposed to petrol and diesel fumes [8] were also similar to our study. Similarly, Aparjita et al. also found statistically decrease in FVC, FEV1, PEFR in petrol pump workers which correlates with our study. However, FEV1\% is decreased but the decline is not statistically significant [9) \]. In our study reduced values of FVC and FEV1, PEFR in petrol pump workers suggests exposure to petroleum products leads to restrictive lung disease with obstructive element. Similar findings were noted by Rao et al. in their study the results reported are reduced ERV, FVC and FEV1 suggesting restrictive and obstructive lung diseases [10]. The decline in observed values of VC, FVC, FEV1 among petrol pump workers indicating restrictive type of lung disease was also observed by Keshavachandran et al. [4] Adverse effects of petrol vapor on the lung functions may occur through several ways. Azeez et al. in an endeavor to find out the effects and potential mechanism of petroleum hydrocarbons on lung tissue conducted blood assay for the lung tissue malondialdehyde (MDA), superoxide dismutase (SOD), catalase (CAT), reduced glutathione (GSH) and histo-morphology of lung tissue in some experimental animals exposed to the petroleum hydrocarbons and explained that the petroleum hydrocarbons causes an increase in lung tissue malondialdehyde (MDA), an indicator of lipid peroxidation. These petroleum hydrocarbons also, decrease the glutathione content and the activities of superoxide dismutase that serve as a primary line of defense in destroying the free radicals. Hence, triggering of oxidative stress leading to the loss of cellular and tissue integrity. [11] Further, the study of Azeez et al. also projected that the exposure to the petroleum hydrocarbons impairs the type II pneumocytes resulting in a decreased production of surfactant and consequently alveolar collapse, ventilation-perfusion mismatch, and hypoxemia. This ultimately leads to hemorrhagic alveolitis, interstitial inflammation, intra-alveolar hemorrhage and edema, bronchial necrosis and vascular necrosis causing defective lung parenchyma. [11] The pollutants from vehicular exhaust and fuel vapours may alter the properties of surfactant which may also contribute to early closure of small airways [12]. The duration of exposure can adverse the effects of petrol fumes in petrol pump workers led to greater pulmonary function impairment. Similar findings were also reported by Uzma N [7], Aprajita [9], Dube S [13].

MVV is considered to be a good guideline for the mechanical efficiency of the lungs. It measures the status of respiratory muscles, compliance of lungs and resistance offered by airways and tissues. MVV is more liable to practice and fatigue effects [14]. In the present study, mean value of MVV was significantly lower in petrol pump workers $(\mathrm{P}=0.015)$. PEFR is the method for assessing the ventilatory capacity with single breath. In the present study, the mean value of PEFR is $6.54 \mathrm{~L} / \mathrm{sec}$ for control and $5.12 \mathrm{~L} / \mathrm{sec}$ for study group. The difference between the mean in the two groups was statistically significant $(\mathrm{P}=0.001)$. Most of the epidemiologic studies of petrol pump workers disclosed a high prevalence of respiratory symptoms. This study demonstrates that certain physiological dysfunctioning effects are constantly observed in occupationally exposed petrol pump workers. This study indicates that exposure to petrol fuel vapours, diesel exhausts and airborne particulate matter at petrol 
pumps leads to restrictive type of lung impairment in petrol pump workers as compared to control.

Since most of the individuals are likely to remain asymptomatic until significant pulmonary damage results. Hence, we suggest periodical monitoring of pulmonary functions which can help in early finding of respiratory illness of petrol pump workers. Petrol pump attendants are not wearing protective masks and because the petrol and diesel exhaust particle are very small in size about $0.2 \mathrm{~nm}$ they can settle down in the respiratory tract. Owing to their small size, these particles have large surface areas so they can carry large number of toxic compounds, such as hydrocarbons and metals on their surface. These particles can remain airborne for more extended period and can be deposited deeper in smaller airways of lung [15] can decrease lung health. Our study demonstrates that certain physiological dysfunctioning effects are constantly observed in occupationally exposed petrol pump workers so they should advise the regular monitoring of health and educated regarding the hazards of gases. This study indicates that exposure to petrol fuel vapours, diesel exhausts and airborne particulate matter at petrol pumps leads to restrictive type of lung impairment in petrol pump workers as compared to control. All workers who are exposed to specks of dust, metal fumes, chemical vapors, and gases which affect the lungs should be given regularly scheduled lung function tests to assess their respiratory health.

\section{Conclusion}

This study reveals a decline in pulmonary functions in petrol pump workers. Till significant damage occurs the people remain asymptomatic, so it is suggested to owners of petrol pumps have regular health checkups to their workers and insist on wearing masks provided. Taking care of protective measures can decrease morbidity. We also suggest that suspected or unhealthy people should be avoided to work in or around petrol pumps.

Acknowledgment: We would like to thank the owner of the petrol pumps who allowed us to conduct the study.

\section{Conflicts of interest: None}

\section{References}

[1] Gupta, S. and Dogra, T. D Indian Jourtnal of Occupational and Environmental Medicine., 2002; vol-6, pg(89-93).

[2] Schuetzle D, Frazier JA. Factors influencing the emission of vapor and particulate phase components from diesel engines. In Ishinishi $\mathrm{N}$, Koizumi $\mathrm{A}$, McClennan RO,Stober W, editors. Carcinogenic and mutagenic effects of diesel engine exhausts. Amsterdam: Elsevier. (1986).
[3] Williams PT, Abbass MK, Andrews GE. Diesel particulate emissions: the role of unburned fuel. Combust Flame; 1989; vol-75: pg1-24.

[4] Kesavachandran C, Rastogi SK, Anand M, Mathur $\mathrm{N}$, Dhawan A. Lung function abnormalities among petrol-pump workers of Lucknow, North India. Current Science. 2006; 90(9):1177-1178.

[5] Leena, C. and Vibha, V., Down to Earth, 15 November 2000.

[6] Periago JF, Prado C. Evolution of occupational exposure to environmental levels of aromatic hydrocarbons in service stations. Ann Occup Hyg. 2005;49(3):233-40

[7] Nazia Uzma, Khaja Mohinuddin Salar B M, Santhosh Kumar B, Nusrat Aziz, Anthony David M and DevenderReddy V. Impact of Organic Solvents and Environmental Pollutants on the physiological function in Petrol Filling Workers. International. Journal Environmental. Research. Public Health 2008; 5(3):139-146.

[8] Singhal M, Khaliq F, Singhal S, Tandon OP. Pulmonary functions in petrol pump workers: a preliminary study. Indian Journal of Physiology and Pharmacology; 51(3): 244-8; 2007

[9] Aprajita,Neeraj Kant Panwar.Sharma R.S. A study on the Lung Function Test in Petrol pump workers.Journal of clinical and diagnostic research, October,vol-5(5);1046-1050;2011.

[10] Rao N M, Petals T S, Raiyani C V, Kulkarni P K, Agarwal A L, Kashyap S K, Chatterjee S K. A dose response relationship between pollution index and pulmonary function in shopkeepers exposed to auto exhaust. IndianJ Environ Protect1991; 11(10):737740 .

[11] Azeez OM, Akhigbe RE, Anigbogu CN. Exposure to petroleum hydrocarbon: Implications in lung lipid peroxidation and antioxidant defense system in rat. ToxicologyInternational. 2012;19(3):306-9.

[12] Choudhari SP, Doiphode RS, Zingade US, Munibuddin A, Badaam KM. Evaluation of airway resistance and spirometry in petrol pump workers: A cross sectional study. IOSR Journal of Dental and Medical Sciences 2013;5(2):69-71.

[13] Dube S, Mungal SU, Kulkarni M. Evaluation of respiratory functions in petrol pump workers at Nanded. International journal of recent trends in science and technology 2013;8 (2):149-152.

[14] Levsan,K: The analysis of diesel particulate. Fresenius ZAnal Chem ; 331, 467-478; 1998.

[15] Wanke T, Formanck D, Avinger M et al. Inspiratory muscle performances and pulmonary function changes. Am Revised Respiratory Disease 1991; 143: $97-100$ 